DOI https://doi.org/10.18551/rjoas.2018-03.21

\title{
RE-ACTUALIZATION OF BALE BANJAR FUNCTION IN DENPASAR CITY
}

\author{
Suryawati Putu* \\ Doctoral Program of Religious and Cultural Studies, Graduate Program, \\ Hindu University of Indonesia, Denpasar, Indonesia \\ Gelgel I Putu, Darmika Ida Bagus \\ Program of Religious and Cultural Studies, Graduate Program, \\ Hindu University of Indonesia, Denpasar
}

\author{
Ruastiti Ni Made \\ Dance Program, Faculty of Performing Arts, Indonesian Institute of the Arts, \\ Denpasar, Indonesia
}

*E-mail: suryawatiputu69@gmail.com

\begin{abstract}
The aim of this study was to know and understand the re-actualization of bale banjar function in Denpasar City. This study was conducted due to the imbalance between the assumptions and current reality. The data sources of this study were some bale banjar-s in Denpasar City, related informants, and previous research findings. All data were collected using observation, interviews, and literature studies techniques and were analyzed using sociocultural evolution, community rationalization, and commodification theories. The research findings showed that re-actualization of bale banjar function in Denpasar City happened due to the high demand of economic space of capitalist economy and the changes of local society's way of thinking; reactualization of bale banjar's form in Denpasar City could be seen from the changes in style and appearance of the spaces that are now widely designed into two floors. The society used the upper floors as a gathering place and the lower floors are rented as a center of economic activity; re-actualization of bale banjar function in Denpasar City had the implications on the way of thinking, the conception of bale banjar form and function and material culture such as the weakening of social relations among krama banjar.
\end{abstract}

\section{KEY WORDS}

Bale banjar, social relation, comminity, economics, changes.

Bale banjar is a gathering place for organization of traditional society in Bali. Bale banjar is a subsystem of Pakraman Village. The main principle underlying social awareness at the banjar level is the pasukadukaan bond which makes the people who are the members of that banjar social organization feel the same destiny and goodness in joy and sorrow. In the bond of social awareness at the banjar level, the society conducts various activities, both social and religious activities. The examples of social activities are cooperatively repairing and cleaning the road, establishing and/or repairing the worship place and other social facilities. The examples of activities in the field of religious ceremonies, they perform ceremonies at Pura Khayangan Tiga, such as performing bhuta yadnya (macaru) and melasti ceremonies. However, although the local society is still doing various social and religious activities in bale banjar until now but many bale banjar-s in Denpasar City has undergone re-actualization. The physical appearance and the function of bale banjar have now changed a lot. However, this phenomenon, that is now common in the Denpasar City, does not make any conflicts in the society. The local society seems to agree and support the occurrence of this re-actualization. It raises many questions whose answers can only be found through in-depth research.

This article was compiled from the research findings that aimed to know and determine the re-actualization of bale banjar function in Denpasar City. Denpasar City is the lifeblood of 
Balinese society. Denpasar, the center of government of Denpasar City and the center of government of Bali Province, currently has implication to various sectors of its society's life. The function and role of money as a medium of exchange or medium for shopping becomes very essential for the local society. By using money, human can buy various necessities of life.

From historical perspective, Denpasar was once the center of Badung Kingdom. Its establishment milestone can be tracked from the pillars of the founding of Puri Denpasar in 1788. In the past, Denpasar City was a favorite park of the King of Badung named Kyai Jambe Ksatrya who lived in Puri Jambe Kesatrya (it is now Satrya market to the north). It was because of Denpasar City was a favorite park of the King of Badung, it can be assumed that Denpasar City which is now one of the nine government districts/cities in Bali Province was the development of the spatial city of the kingdom and Puri Denpasar became the center of the government at that time (Wiasti, 2010: 52).

Denpasar City consists of four sub-districts namely East Denpasar Sub-district, South Denpasar Sub-district, West Denpasar Sub-district, and North Denpasar Sub-district. Generally, the economic growth of Denpasar City has accelerated and exceeded the economic growth of Bali Province. It happens because in addition to the center of education, Denpasar City is also a trading center in Bali which causes many entrepreneurs and investors outside Bali are competing to develop their business in Denpasar City. Moreover, the rapid development of tourism in this city makes Denpasar increasingly being targeted by migrants to pursue their fates and earn sustenance. The emergence of various types of business in the field of tourism in Denpasar City such as hotels, restaurants, and travel services that absorb a lot of labor proves that Denpasar is quite successful in developing the tourism sector. This high labor absorption in this sector indicates that the tourism life is flexible enough and is able to position workers based on the qualifications possessed by the workers. High activity of the society in this sector makes the pulse of Denpasar as if it never stops. It runs from the morning to morning again in which life in this city seems never sleep even for a second. In entertainment venues including nightclubs or traditional markets such as Badung Market, Kreneng Market and other markets in Denpasar City seem never stop for almost 24 hours. It proves that the activity of the society in Denpasar is very high.

In socio-historical perspective, most people in Denpasar City embrace Hindu religion which adheres to the values of Balinese tradition and custom culture that have been inherited from their ancestors. Regarding to this, the typology of Denpasar society, which is an integral part of Balinese society, is not entirely different from the characteristics of Balinese society in general. One interesting feature of the social and cultural systems existing in Balinese life is the development of units of social unity, such as villages and banjar-s. According to Suda (2008: 30), village is a form of social unity whose activities are always associated with the issues of custom and religion. On the contrary, the official village is an administrative unit so that its activities are more centered on administration and development. Although both villages engage activities in different fields but in running the wheel of life, both have a functional relationship. It is because the physical construction undertaken by the official village is a unity that cannot be separated by the spiritual development that is carried out by those traditional villages.

In socio-cultural perspective, the society of Denpasar City, especially those who embraces Hindu religion adheres to patrilineal kinship system. The implementation of rights and obligations in the family is based on straight paternal lineage. The orientation of cultural values that is adopted by the society of Denpasar, especially those who embraces Hindu religion is prioritizing harmony in living their lives. By adhering to the value of tri hita karana philosophy in living their lives, the society of Denpasar City always emphasize the principle of harmony in their relation with God Almighty (Ida Hyang Widhi Wasa) which is called parahyangan element, harmony relationship among human being which is called pawongan element, harmony relationship between human being and their environment which is called palemahan element.

The institutional system of the custom which is still functional in Denpasar City includes pakraman village and banjar (Sukarma, 2012: 98). Pakraman village in customary law of Bali 
has a unity of tradition and manners that are traditionally tied up in a Pura Kahyangan Tiga (village pura). Meanwhile, banjar is a subsystem of pakraman village. The main principle underlying the social ties of the banjar is the pasukadukaan bond; feeling the same destiny, both in joy and sorrow. In this banjar bond, the society performs various activities including social, cultural, and religious activities.

The aim of the study was to know and understand the re-actualization of bale banjar function in Denpasar City. Basically, as a gathering place of society, bale banjar must have a form that is in accordance with its function. However, the reality was different. Although the local society still occupy bale banjar as their gathering place for social, cultural and religious activities up to now, however in reality this re-actualization continues without causing conflict. It raises many questions:

Why does re-actualization of bale banjar function happen in Denpasar City?

How is the form?

What are the implications for the lives of the society?

\section{METHODS OF RESEARCH}

This study implied qualitative method. The data sources of this study were some bale banjar-s in Denpasar City, related informants, and previous research findings. All data were collected using observation, interviews, and literature studies techniques and were analyzed using socio-cultural evolution, community rationalization, and commodification theories.

\section{RESULTS AND DISCUSSION}

Re-Actualization of Bale Banjar Function. The occurrence of re-actualization of bale banjar function Denpasar City cannot be separated from the development of culture and the transformation of public awareness in interpreting their traditions and social lives. The society of Denpasar, with high mobility level, understands the life more practically and efficiently. The intensity of social relation pattern among the people has decreased so that this social life needs special momentum. Social spaces including bale banjar that serves mainly for religious and socio-cultural activities faded along with the modernization of society life in Denpasar City.

Modernity is being identified as a construct of modern culture that stands on the principles of ratio, subject, identity, ego, totality, absolute ideas, linear progress, objectivity, autonomy, emancipation, and binary opposition (Haryono, 2005: 35). Habermas (Lubis, 2004: 6) uses the term "modernization" as a process of cultural differentiation and social autonomy. Therefore, modernism is understood as the impact of the differentiation process. If modernization is a process of differentiation and cultural autonomy, modernity is a massive social and cultural change associated with industrial capitalist society. Berger (2003) stated that modernization or modernity is a pluralization of values, norms, meanings, and symbols that lead to cultural segmentation and diversity on way of life. Abraham (1991: 206) explained that modernization is a comprehensive process of economic growth, social mobilization, and cultural expansion. Economic growth is defined as a progressive process of the economic welfare of the population in general. Social mobilization is defined as a process of greater involvement in secondary groups, new patterns, anticipatory socialism, and the creation of new reference groups that are separate from the traditional ones. Furthermore, cultural expansion is defined as a prescriptive process of prescriptive action, extension of alternative spans, and initiation of new patterns of socialization and behavior.

According to Durkheim, modernity is determined by organic solidarity and the weakening of collective consciousness. George Simmel said that modernity is determined by two interconnected sides, the city and the money economy. The city is the place where modernity is centered or intensified, while money economy causes the spread of modernity and its extension (Ritzer 2003: 551). Giddens defined that modernity consists of four fundamental institutions, namely capitalism, industrialism, surveillance capabilities, and the control of the means of violence. Capitalism is characterized by commodity production, 
private ownership of capital, labor without property, and a class system derived from these characteristics. Industrialism involves the use of natural resources and machinery to produce goods. Surveillance capabilities refer to the surveillance on the activities of individual citizens in the political environment. The dimensions for the control of the means of violence are military forces including the industrialization of war equipment (Ritzer and Goodman, 2004: 555).

In addition to the four modernity institutions, Giddens emphasized the role of interpretation and system of meaning in human life. He placed structures and actors as mutually supportive dualities. The point is that humans are active and creative subjects. Therefore, the structure is outside the individual. The structure has its existence inside the mindset that contains the rules and resources, including knowledge, abilities, and practical skills obtained by a person through socialization. Giddens considered that structure is a medium and outcome of action. Structure becomes medium because one cannot act without the knowledge and the ability that has been considered before. Structure becomes a result because the cultural pattern is reproduced when it is used. Structuralization captures images of social life as a reciprocal process between individual actions and social forces. Humans produce the social order because of the need for trust and fear of uncertainty that so-called ontological security. Social life is turned to routine and conventional so that everyone feels safe (Sutrisno and Putranto, 2005).

In the perspective of modern society, space is increasingly being released from its local and place (Ritzer, 2003: 555). The society of Denpasar City argues that their tradition, especially the utilization of bale banjar has changed. The change takes place in the management of bale banjar. The traditional characters of bale banjar also get a new interpretation based on the condition of the current society. Modern way of thinking of this krama banjar can be seen from the design of bale banjar which is built as multifunctional. It means that they no longer consider bale banjar as only a product of tradition that the role and traditional function must be kept strictly. This modern nuance is presented by taking on other roles outside of its traditional role. It is not a taboo to use bale banjar for activities outside of social, custom, and religious activities. When it is traced back, as anthropologically portrayed by Covarrubias (2014), that a banjar should have meeting rooms, organizational meeting rooms, and kulkul towers to summon society to gather, kitchens with all kinds of cooking furniture, gamelan gong and gedong for storing dance equipment. It used to be said that Balinese men spent their spare time in bale banjar, gossiping, poking chickens, watching the practices of sekaa-sekaa gong, or just sitting around. At that time the bale banjar really became a public space for krama banjar. Almost every day, banjar is filled with social activities of the krama banjar. The ancient bale banjar portraits revealed by Covarrubias (2013: 67) are now very different from the current facts.

Currently, bale banjar that was previously a socio-cultural space, is now an economic commodity space. The economic burden of krama banjar is considered to be quite heavy to finance all religious, cultural and social activities, including the maintenance cost of bale banjar and pura. According to people, renting some bale banjar spaces permanently can economically handle the needs of krama banjar. The economization of bale banjar provides advantages for krama banjar. In addition, the administrators or prajuru will not be bothered for collecting the dues of banjar members because all have been borne by the tenant of bale banjar space. The practical and economical dimension in managing bale banjar is greatly experienced by krama banjar.

In the modern society life, with the system of capitalism in understanding the money, the banjar administrators are not naive and openly affirm their attitude in the effort to make a commodity for bale banjar. It means that the effort to rent bale banjar for economic interests is not considered as something that is forbidden to do. The krama banjar-s also have no guilt and moral burden to do business in their bale banjar space. Moreover, the aim of renting bale banjar is to ease the burden of the krama. The commodification process of bale banjar is carried out through a mutual consensus. The economic orientation changes the way of krama banjar thinks about their banjar. They are more likely to think of economic pragmatism to ease the social and cultural burden that has been endured by the krama banjar. It shows 
that economic interest is considered to be at the above level compared to cultural and social interests. It is a representation of the pragmatic and economical way of thinking of modern society. To carried out an activity, it must have a certain economic impacts.

The development of city tour in Denpasar becomes one of the causes the krama banjar-s rent bale banjar space for the merchants. It means that it has already carried out since the 1980s in which krama banjar in Denpasar City consider to take business opportunities to rent bale banjar. The benefit of renting bale banjar is used for social, religious, and cultural activities. The benefit of collecting the dues and renting the bale banjar is used to build a more majestic banjar of two floors. The goal is to accommodate the merchants on the first floor and for other social activities on the second floor. However, it is recognized that renting bale banjar is a solution to answer the economic problems of krama banjar. Bale banjar which was previously considered as a burden for demanding economic expenditures for social and religious costs, it is now is considered as the economic asset of krama banjar since the tourism aspect is developing in Denpasar City.

The Form of Re-Actualization of Bale Banjar Function. The form of re-actualization of bale banjar function is a representation of the adaptive character of banjar society in facing the changes and social complexity as the result of modernization. The re-actualization of bale banjar function is the result of adaptation to the changing conditions. The following findings will present some field observations about the form of re-actualization of bale banjar function in Denpasar City. Meanwhile, qualitative change is a change and it is a new type or form that replaces the old type and form. Definitely, the qualitative change is the result of the previous quantitative change. When quantitative changes are accumulated over certain period, it will result a transformation that is termed by qualitative change.

According to Sanderson (2003: 64), many evolutionists argued that the direction of the major tendency in sociocultural evolution is the increasing complexity of society. Robert Carneiro (1972), for instance, stated that inside the reality is what is meant by evolution, namely changes that lead to the increasing complexity of society. In addition, the use of other concepts will undermine and diminish its understanding.

The sociocultural evolution has many dimensions. The sociocultural evolution is a process of change; when a sociocultural form is shifting to another. The sociocultural evolution emphasizes the process of qualitative change rather than quantitative change. Quantitative change is a change from less-amount to more-amount and vice versa. Therefore, it has many direction tendencies. One character of sociocultural evolution is adaptation. According to Sanderson, sociocultural evolution is an adaptive outcome of changing conditions. The society thrives to meet new demands and needs. However, the society does not always face new demands and needs. In an unchanging situation, the existing sociocultural patterns are sufficient to solve basic human problems and no evolutionary changes are necessary. Both will occur depending on the underlying conditions. It means whether the conditions that are necessary for the existence and welfare of human beings are changed or remained the same.

Triguna (1997: 91) mentioned that modernization and globalization have introduced new values in the traditional environment. Members of the community advocating a tradition always experience the process of sociocultural differentiation and a generalization of the values, norms, and meanings that come along with it. In relation to culture, the shift has contributed to knowledge as a cultural unit. Everyone, whose knowledge system has been touched of new values, tries to give new meaning to the previous order, not to mention the things that are normative, as written in the rules of custom and tradition. A process of mutual destruction and integration occurs in a mechanism that so-called adaptation improvement or adaptation with modification through a process of understanding and interpretation toward the abstraction level in general acceptance. Adjustment effort contains a double meaning in which human beings try to adjust their lives with the environment. The re-actualization of bale banjar function in Denpasar City is one form of society efforts to adopt new values to their lives. This process leads to more adaptation with modification. In term of cultural infrastructure, bale banjar undergoes a functional modification process sociocultural space function to an economic space through re-actualization. One form of re-actualization of bale 
banjar function is as a place to run a cooperative business as presented in the following figure.

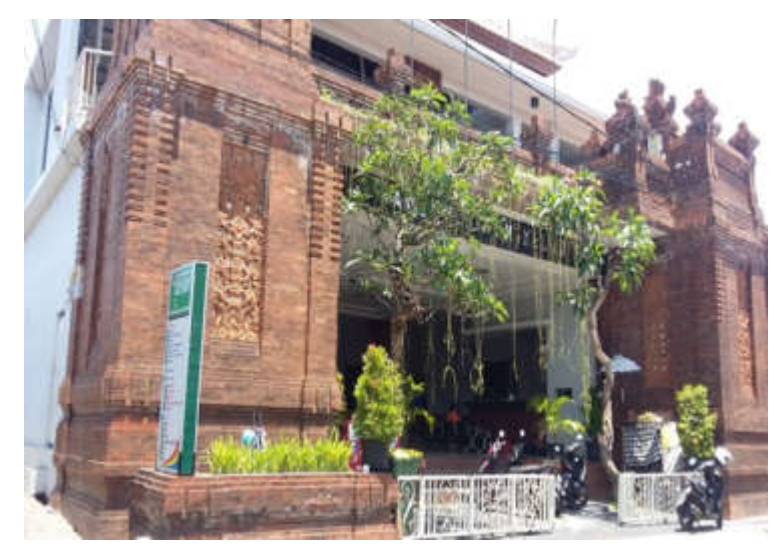

Figure 1 - Bale Banjar of Binoh Kelod that is rented as a cooperative office (Documentation: Putu Suryani, 2017)

From the physical appearance, bale banjar above is included in magnificent category. The pattern of the building is modern but it contains Balinese nuance. The side part is a sturdy brick building made of brown brick - typical of bebadungan style. In the front yard of this banjar, there are two jepun trees. By passing by this banjar, people will be amazed because the physical appearance of this banjar is like a luxury house. Bale Banjar of Binoh Kelod is built on two floors. The construction was completed in 2014. The cooperative of Kertha Sedana is intended to ease the economic burden, especially the krama banjar of Binoh Kelod. The existence of cooperative of Kertha Sedana is considered to contribute economically at large scale in the middle of difficult and heavy burden of mebanjaran. The existence of cooperative in front of this bale banjar porch is not free. The administrators of banjar also put the rent for the cooperative office. The benefit from renting the bale banjar space for cooperatives is used for banjar cash in support of all kinds of social, cultural and religious activities. Triguna (1997) said that one sign of the characteristic changes of the Balinese society is to be economic human, which means that the economy becomes a measure in human life. Every morning, Bale Banjar of Binoh Kelod becomes a cooperative office that cannot be interfered by any activities, including other social activities.

Krama banjar is really conscious in managing their bale banjar space into a cooperative office. Even bale banjar front space is considered very strategic for this saving and loan business. In addition, it is very close to the traditional market. This opportunity is taken by krama Banjar Kayangan, rather than letting the bale banjar empty and working only at certain times. They also understand that bale banjar is not monolithic - that it only refers to a single function, but can be a multifunctional space, especially in economic terms. As mentioned by Piliang (2004: 455$)$ that all social reality is a process. It means that whatever happens in this world contains contradictions and is always in the process of transformation. It is reflected to bale banjar which is rented as a trading place.

The society of Denpasar City not only considers that bale banjar is a place to preserve traditional social ties and cultural activities only. Changes in cognitive structure with instrumental rationality due to modernity makes people think more economically about the function of bale banjar. Therefore, it is not surprising that bale banjar spaces are now reactualized as a trading place to earn money. The phenomenon of re-actualization of bale banjar function into a trading place can be seen in Banjar Titih Tengah, West Denpasar Subdistrict. They do trading activity from morning until afternoon. The banjar administrators are consciously rented bale banjar to fruit sellers to increase the income of the banjar economy. Marx mentioned in Turner (2003: 126) about commodity fetishism that it only occurs in capitalism of economic basis which causes material interests to spread into every social structure, including the public consciousness structure. As revealed by Abraham (1991: 209) 
that modernity is characterized by economic growth, especially the growth of specialization of economic roles and unit of economic activity of production, consumption and marketing. The fact is that it is impossible to separate the production economy from the local cultural ideology. It happens because the artifact, image, representation, and even feelings and structures of cultural psychic have become part of the world economy.

Denpasar is transforming into a city of tourism with the modernization of development. Indirectly, it opens new spaces for industrial development or economic activity. Not to mention also the possibility that social and cultural spaces are functionally renewed in order to support its life and survival. Reflexivity to the culture and tradition is carried out to adjust to the current development of the era that continues to advance all aspects of human life, especially in Denpasar City. In this context, social space, such as bale banjar is always reactualized functionally and presents new forms. This bale banjar appearance does look different from the front side. Bale Banjar is located right in the middle of the hubbub of economic activity of the traders in Kereneng market. In the afternoon, this bale banjar front room is filled with the merchant carts at Kereneng Market. The appearance of Bale Banjar Kereneng is very different from other bale banjar. It is because of the front side of bale banjar storefront has already been plastered by the signature of makeup training from Agung Salon. The bale banjar space that is used as makeup training is not only on the first floor but also on the second floor. It means that the entire bale banjar space is used for the needs of Agung Salon. Nevertheless, Agung Salon bears all kinds of religious, social, and cultural costs in Banjar Kereneng. Therefore, the local community never minds if its social and cultural space is commercialized to Agung Salon as the hiring party.

Here, the productivity of bale banjar is no longer measured from the results of carrying out organized social activities or rebuilding solidarity among krama banjar, but the parameters used are the economic benefits. Bale banjar is considered as productive when it generates profits economically. It means that bale banjar is not a standard, conventional, and final cultural product. Krama Banjar is always adaptive and negotiable to the dynamics of change that impact on life in banjar. Their attitude is also very practical by utilizing bale banjar effectively and efficiently. Many institutions make cultural transformations to realize efficient (economic) and rational (in making decision) values that are free from tradition, custom, and communal bonds. As the banjar manners-in this context-actualize the bale banjar for the survival of the banjar itself. It means that what happens currently in the bale banjar is a mirror or representation of the rate of social and cultural changes in urbanized society that undergo modernization. It is a form of adaptation with modifications that is made by the banjar administrators to be able to maintain its existence in the midst of the development of the current era. The people of Denpasar City respond to modern influences by re-actualizing bale banjar function in more functional forms without neglecting the main function of bale banjar as a gathering place of society in maintaining its social, cultural and religious life in this global era.

The Implication of the Re-Actualization of Bale Banjar. Kinship is a society unit that becomes one of the pillars of Balinese society structure. The Balinese kinship has approximately the same pattern but it uses different terms and shapes to each other. Various terms are used to refer to this kinship, such as soroh, warga, krama, pasametonan, and preti sentana. All of these terms refer to the unity of the lineage or ancestral commonality. Bonds and kinship are shown by the word nyama. The word nyama comes from the Balinese word sama which means the same ancestor. Another term is sameton that comes from the Balinese word sa which means one and metu which means out or born. Therefore, sameton means born from one mother.

The other unit of society is the pakraman which is the local society unit. Pakraman is formed based on a social contract of agreement to organize and develop a common life according to the joys, the harmony of life, and mutual cooperation in living the joys and sorrows in a place or village. This formally written social contract is called awig-awig.

The members of pakraman are plural in terms of origin (geographical) and lineage (genealogical), but is egalitarian in the determination and execution of rights and obligations. In addition to be united by the common place which is commonly called by wewidangan or 
wewengkon, pakraman village is also united by the order of rights and obligations in performing worship and performing religious ceremonies at the main Pura Kahyangan Tiga, namely Pura Desa or Pura Bale Agung, Pura Puseh, and Pura Dalem. In addition, other puras such as Pura Kahyangan and Pura Prajapati are a unity with setra or "cemetery", and Pura Melanting is a part of the market of pakraman village.

In the beginning, the residents or krama of pakraman village are a collection of a number of core families with different backgrounds of origin, both geographically and genealogically. Over time, these core families evolve into extended families and formed their respective kinship units in their villages into branches or twigs of their own pamaksan, dadya or pasametonan. The residence house, which was originally the residence of the core families that lived in a banjar in particular pakraman village, then became umah tua, umah gede, or so-called umah desa (Geertz, 1975: 40).

Most new families moved from the old house. They build new houses on family estate land or on a new land they buy. This process is called ngubu, mondok or ngarangin. The new core family houses that are built outside the old house are called kubu or pondok. Culturally, the word "mulih" (derived from the word "mula" or the beginning) is generally only used for the meaning of going back to the old house or umah desa, while for the meaning of going back to kubu or pondok, they use expression ke kubu or ke pondok.

Sanggah or merajan, a place of ancestral worship of the family in the old house, is generally developed into sanggah gede or merajan agung. In addition, all the descendants of the core family gather and carry out religious ceremonies on the piodalan day, the day of celebration when routinely the whole family members of one pamaksan worship their ancestors. Kinship relationship among the members of pamaksan in pakraman village is generally known through oral stories and treated by institutionalizing periodic meetings (pasangkepan or simakrama). In addition, there are also activities of mutual help and visiting each other in the execution of various ceremonies in the growth and the life cycle of their extended families. Equating the day or the tegak of piodalan ceremonies generally marks the equation of kinship relationship (Geertz, 1975: 80).

In the equality of rights and obligations, it emphasizes the importance of the principle of reciprocity; it is the obligation to give in the hope of receiving the same things. The synergy of these two factors causes indigenous villagers of Bali tend to be homogeneous in the reference of values, characters, and choices to the available alternatives in the relationship of interpreting and understanding the physical social environment. This fact is at least represented from the coveted relationship of the principle of sagulik, saguluk, salunglung sabayantaka. Triguna (1997: 141) mentioned that every krama is obliged to maintain the harmony with others by as deliberately as possible trying not to stand out above other krama. Conformist and egalitarian actions are always applied to a pattern. It means that it can be carried out again in the future in the same economic way. Habituation will bring the consequences that human beings no longer need to redefine every step-by-step situation. Habituation is the beginning of the institutionalization process. Conformist and egalitarian actions are finally institutionalized, which means that the segment of activities of every krama has been placed under social control. The typification of this interaction will be realized because human capabilities can interpret and predict the actions of others, which means that their overall interactions can be foreseen. It is the beginning of the formation of an objective world; a social form that can be passed on to the next generations.

Currently, banjar holds a very important role to maintain harmony and the pattern of social relations of Balinese society. They are bound in a social ethic based on sukerta tata pawongan. In the life of krama banjar, the principle of conformism is also held firmly so that between one krama banjar and the others are egalitarian. Currently, banjar has the function of binding krama in micro-social relations in the body of pakraman village. The principle of mebanjaran which is held up so far is pasuka duka, gotong royong, menyama braya, in both social and religious activities.

Covarrubias (2013: 65) explains that banjar is a cooperative society of people who are obliged to help each other in marriage ceremonies, home parties, especially during the ceremony of pengabenan. Here, banjar is illustrated as a place of social relationship based 
on the religious dimension. It means that after entering into the life of grhasta asrama, someone has been legitimate as a concrete krama in the banjar. They are required to participate in all social, cultural and religious activities in the banjar. In short, banjar is a binding means of social relationships. Through a symbol named kulkul, their social relationships are built to solve the problems and activities that are going to be carried out. The decision is taken based on mutual agreement in a paruman or sangkep banjar. Starting from the past, banjar has become a public space of krama banjar. They make banjar as a place to discuss, say hello, and make direct contact. Banjar became their place to knit social relationships to strengthen pasukaduka that becomes the principle of mebanjaran.

The Implication of The Re-Actualization of Bale Banjar. Changes in the current era have implications for the pattern of social relationships in bale banjar. Durkheim (Ritzer, 2003: 551) stated that modernity is characterized by the weakening of collective consciousness. The re-actualization of bale banjar function in Denpasar City which is more on the side of economic effectiveness currently has implication on the weakening of social relationship between krama banjar. The intensity of krama meetings in the form of sangkep activity began to be reduced because bale banjar spaces have been used for economic business. This phenomenon also occurs in several banjar-s in Denpasar City, such as in Banjar Titih Tengah, Denpasar. Since it is rented to the fruit sellers, there is no more krama activity in bale banjar, especially in the morning. Bale banjar of Titih Tengah is no longer a place where people sit together and have conversation, especially in social activities, because the bale banjar space has been rented to the fruit sellers. Similarly, sangkep banjar activity is no longer carried out once a month, but it is carried out once in six months. It means that the momentum of krama banjar meeting in sangkep activity is held only twice a year.

The modernization of banjar society in Denpasar has implications for the slackening of traditional social bonds. Formerly, bale banjar became an alternative space when there was one krama banjar who did not have enough space in carrying out religious activities at home, especially in the wedding ceremony. In that case, bale banjar served as an alternative to these activities. But currently, not many people use bale banjar for those activity. They choose to close the road to run the manusa yadnya activity. It is also found in Binoh Kelod. However, the administrators of the banjar argued that bale banjar has become a cooperative office. A more extreme situation occurs in Banjar Kereneng, Denpasar.

As a system, culture has content or is referred to as the content of culture, hereinafter referred to as cultural universals as initiated by Kluckholn. The contents of culture, according to Kluckholn, are live equipment systems, livelihood systems, community systems, languages, arts, knowledge systems, and religious systems. The contents of the culture are also referred to as elements of culture in which will form a cultural system in a society life. Huntington (2003) suggested that culture is the basic values, attitudes, beliefs, orientations, and fundamental presumptions that are prevalent among people in a society. Abdullah (2006: 51) explained that culture is not just as a frame of reference that guides behavior in various social practices, but rather as goods or materials that are useful in the process of self- and group-identification. Culture has established a belief that culture is a blue print that becomes a compass in the course of human life and a guide in their behavior.

From the culture system, the re-actualization of bale banjar function which is carried out consciously by krama banjar indirectly changes the way of thinking, idea, and public conception about current bale banjar function. The idea and conception of agrarian society (pre-modern) about bale banjar is very different from modern society. Changes in the way of thinking about the function of bale banjar are heavily influenced by the modern culture of a capitalistic economy. The emergence of re-actualization of bale banjar Denpasar City became an indisputable fact that there has been a transformation in the level of ideas about Balinese cultures.

Traditional society is a contrast of modern society. Modern society tends to be individualistic, self-, competitive-, and achievement- oriented. In contrast, traditional society sees the importance of inheritance and innate values. In addition, they also tend to be collective and communal character; it is a personal and emotional relationship. The values of 
communalism in bale banjar are replaced with effective and efficient economic value. The society of Denpasar City not only sees bale banjar function in socio-culturally way, but also the function in economically way. Thus, it can be asserted that the re-actualization of bale banjar function in Denpasar City affect the way people think, especially the younger generation about bale banjar.

The economization of bale banjar passed on by the older generation to the younger generation that will take place on an ongoing basis because the effort is considered as legitimate and not prohibited. The younger generation also inherits the idea that bale banjar has multifunctional value, in which it is not only socially functioning. Based on this situation, the following time, it is predicted that the re-actualization of bale banjar will occur more massif, even up to the village level outside Denpasar City. The re-actualization of bale banjar function also changes the culture system or subjective culture of society in bale banjar. At least, by using the definition of culture as a system of ideas, the re-actualization of bale banjar function in Denpasar City has great implications for the changing system of ideas and the way of view of society about the function of bale banjar. The modernization of Denpasar as the capital city of the province with the entry of economic market also change the way of thinking of the society. The economic demands in managing the banjar become the trigger of the society to reinterpret bale banjar function to be in accordance with the development of the era and be economically profitable.

In addition to the subjective implications of culture, the re-actualization of bale banjar function also has implications for the culture in objectively way or material culture. It can be seen from the change of style and appearance of bale banjar spaces in Denpasar City. There are increasing numbers of bale banjar which are designed into two floors. Commonly, the first floor is used to be managed by banjar, either being rented or used as a cooperative office. Meanwhile, the second floor is used for social and cultural activities. The sharing of bale banjar flooring is adjusted; the first floor is used for savings and loan cooperative business, while the second floor is used for social activities. Pura and bale kulkul which are the characteristics of bale banjar are no longer placed on the first floor but is placed on the second floor. With the development of such a pattern, it can be analyzed that the banjar administrators carry out a cultural adaptation in facing the changing of time. Adaptation involving this material culture can be seen from the efforts of the banjar administrators to add bale banjar floor.

Changes in cultural elements can be caused by the existence of social movements so that cultural adaptation is required. Inside the cultural adaptation, every individual needs another individual in order to respond and create their social world. The need for the social world reinforces the assumption that humans cannot live well if they are alienated from their social environment. Humans should always try to maintain harmonious relationships with the nature and the environment around them based on the principle of mutual relationships. Adaptation, in this case, means that a system must cope with a serious external situation. The system must adapt to the environment and adapt that environment to the needs. Kaplan (2000: 112) stated that adaptation is a process that connects cultural systems with their environment. Sanderson (2003: 68) mentioned that adaptation is a social trait (nature or social behavior) that arises as a result of the needs, goals, and desires of the individual. Adaptation is closely related to a socio-cultural pattern because new socio-cultural forms as an adaptation. Changes to the form of bale banjar development are an adaptation effort of a modern and market-oriented culture. The social and economic burden of mebanjaran has implications for the effort to commercialize bale banjar spaces so that the income can be used for banjar activities. This effort is carried out so that banjar and krama banjar can survive in the middle of the dynamics of modern life that brings with it new values.

\section{CONCLUSION AND SUGGESTIONS}

Based on the above discussion, it can be concluded that the re-actualization of bale banjar function in Denpasar City occurs due to the high demand for economic space over the emergence of capitalist economy and the changes of local society's mindset. The occurrence 
of re-actualization of bale banjar function in Denpasar City cannot be separated from the development of culture and the transformation of awareness of local society in interpreting their traditions and social culture. The society of Denpasar City, with a high level of mobility, understands the modern life that puts forward the practical and efficient aspects. In modern society life, everything is considered to have economic value including cultural objects such as bale banjar. They define the cultural capital such as bale banjar can be developed as economic capital.

The form of re-actualization of bale banjar Denpasar City can be seen from the change in style, the appearance of bale banjar spaces that are now widely designed into two floors. The upper floors are used by the community for a gathering place, while the lower floors are used for a place to sell, cooperatives, parking lots, and other centers of economic activity. The change in local society's way of thinking from conventional ways of thinking that puts physical wholeness traditionally has changed into a more modernized way of thinking and putting forward efficient and economical factors in which it leads to their modern, communal change of mindset toward the creative economy. The parameter used is the benefit in the economically way.

The re-actualization of bale banjar function in Denpasar City has implications for the economy and culture of the local society, including the way of thinking, conception, ideas about culture, and cultural objects. From an economic perspective, it can be seen that currently with the re-actualization of bale banjar, the society is thoroughly obtaining financial input from renting the bale banjar. There is also a change in the function of banjar as a place of beauty course in which they accidentally get the financial input from the emergence of tourist attraction in the form of city tour to the related banjar. From the cultural system, the reactualization of bale banjar function which is carried out consciously by krama banjar indirectly changes the way of thinking, idea, and public conception about current bale banjar function. Furthermore, the implications can also be seen from the material culture. It can be seen from the changes in the style and appearance of bale banjar in Denpasar City which has a few color of traditional Balinese architecture. There are a lot of bale banjar which is designed into two floors.

The findings in the study include field findings and theoretical findings. Field findings indicates that people in Denpasar City have now been accommodative and adaptive to the changing of times or modernization. The theoretical findings of this study affirmed Sanderson's theoretical mind that socio-cultural evolution has an adaptive sociocultural evolutionary character and affirmed Theodor Adorno's commodification theory that currently many objects have been made as something of more exchange value that is considered a false enlightenment of capitalism.

Based on the findings of the study, it is suggested to the society, especially krama banjar to continue to strengthen its cultural identity as a social foundation in bale banjar. It is undeniable that the role of banjar is very important for Hindus people in Bali especially Denpasar City. Banjar must still function as a social space and maintain the culture, tradition, and religion collectively. It can be concluded that bale banjar is a stronghold of Hindus people in maintaining cultural and traditional identity. Re-actualization that is carried out as an adaptive and negotiated effort against the development of the times should lead to the spirit of cultural identity preservation, not the contrary, where the re-actualization eliminate the collective values of communal including cultural and religious bale banjar in the global era instead.

For the government, both the executive and the legislature, it is suggested to participate in the development of bale banjar in Denpasar City so that the efforts that have been developed are not contrary to the cultural values of the local society. It is important because during this time the banjar administrators run independently in managing bale banjar which then causing a fear to the loss of continuity and sustainability of mebanjaran. This attitude is performed because they feel a very heavy burden in managing the banjar. The expenditures are considered to be burdensome, especially for krama banjar that are categorized into poor households. The obligation to perform religious ceremonies which are the responsibility of the banjar is also increasingly urgent. In this case, the government must 
take a strategic role because mekarma banjar is a cultural asset that must be maintained. If the banjar administrators cannot maintain the existence of its function then it is feared that Balinese people will experience a social crisis.

It is suggested to the administrators of pakraman village or the board of pakraman village to participate in maintaining the tradition of mekrama banjar in Denpasar City. In addition, the board of pakraman village should provide understanding and socialization of the importance of mekrama banjar although the culture of the society in Denpasar City has been advanced. However, if the tradition is faded, it will lead to the loss of the values of Balinese cultural traditions that are caused by globalization.

It is recommended to the tenant to keep the agreement and keep the physical condition of the banjar in order to avoid misunderstanding of society for the sake of sustainability of a good relationship in social, cultural and economic ways.

\section{REFERENCES}

1. Abdullah, I. (2006). Konstruksi dan Reproduksi Kebudayaan. Yogyakarta: Pustaka Pelajar.

2. Abraham, F.M. (1991). Modernisasi di Dunia Ketiga: Suatu Teori Umum Pembangunan. Yogyakarta: PT Tiara Wacana Yogya.

3. Berger, P.L. (2003). Kebangkitan Agama Menantang Politik Dunia. Yogyakarta: Arruzz.

4. Covarrubias, M. (2014). Pulau Bali. Denpasar: Pustaka Larasan.

5. Geertz, C. (1975). Khinsip in Bali. Yogyakarta: Yayasan Bentang Budaya.

6. Haryono, Y.M. (2005). Melawan dengan Teks. Yogyakarta: Resist Book.

7. Hidayat, K. (2009). Wisdom of Life. Jakarta: Kompas.

8. Huntington, S.P. (2003). Konflik Peradaban Paradigma Dunia Pascaperang Dingin. Terjemahan dari The Clash of Civilizations: Paradigms of the Post-Cold War World oleh Ahmad Faridl Ma'ruf. Yogyakarta: IRCiSoD.

9. Kaplan, D. (2000). Teori Budaya. Yogyakarta: Pustaka Pelajar.

10. Koentjaraningrat. (2004). Manusia dan Kebudayaan di Indonesia. Jakarta: Djambatan

11. Lubis, A.Y. (2004). Masih Adakah Tempat Berpijak bagi Ilmuwan. Bogor: Akademia.

12. Piliang, Y.A. (2000). Dunia Yang Berlari.Jakarta: Grasindo.

13. Ritzer, G \& Douglas, J.G. (2004). Teori Sosiologi Modern. Jakarta : Prenada Media.

14. Ritzer, G. (2003). Teori Sosial Postmodern. Yogyakarta: Kreasi Wacana.

15. Sanderson, S. (2003). Sosiologi Makro. Sebuah Pendekatan Terhadap Realitas Sosial. Jakarta: Grafindo Persada.

16. Storey, J. (2004). Teori Budaya dan Budaya Pop. Yogyakarta: Pustaka Pelajar.

17. Suda, I.K. (2008). Anak dalam Pergulatan Industri Kecil dan Rumah Tangga di Bali. Yogyakarta: Aksara Indonesia.

18. Sukarma, I.W. (2012). "Hegemoni Modernitas dalam Religiusitas Umat Hindu di Kota Denpasar." Disertasi pada Program Doktor Universitas Udayana Denpasar.

19. Sutrisno, M., \& Putranto, H. (ed). (2004). Hermeneutika Pascakolonial-Soal Identitas. Yogyakarta: Kanisius.

20. Triguna, I.B.G.Y. (1997). "Mobilitas Kelas, Konflik, dan Penafsiran Kembali Simbolisme Masyarakat Hindu di Bali." Disertasi. Bandung: Universitas Padjadjaran.

21. Turner, B.S. (2003). Agama \& Teori Sosial. Yogyakarta: IRCiSoD.

22. Wiasti, N.M. (2010). "Konstruksi Kecantikan Tubuh Perempuan Bali yang Berkarier di Kota Denpasar, Propinsi Bali." Disertasi untuk mencapai gelar doktor, pada Program Doktor (S-3) Kajian Budaya, Program Pascasarjana, Universitas Udayana, Denpasar.

23. UU No.1 Tahun 1992 tentang Pembentukan Kota Madya.

24. Tim Penyusun Profil Kota Denpasar, 2014. Denpasar: Pemerintah Kota denpasar. 